\title{
Genetic contamination of traditional products
}

\author{
E. Kwan Choi ${ }^{*}$ \\ Iowa State University, Ames, IA, USA \\ City University of Hong Kong, Kowloon Tong, Hong Kong
}

\section{A R T I C L E I N F O}

\section{Article history:}

Received 30 May 2011

Received in revised form 18 October 2012

Accepted 22 October 2012

Available online $\mathrm{xxxx}$

\section{Keywords:}

Genetic contamination

Terminator genes

\begin{abstract}
A B S T R A C T
Cross-pollination can be caused by birds, insects and wind. Genetically modified (GM) seeds are produced each year in a controlled environment to maintain their purity. However, pollen from the GM crop can be transferred to traditional crops. When the GM crop producers are in long-run equilibrium and buy seeds from a monopolistic seed producer, the resulting market equilibrium is identical to that when a seed monopolist produces the GM crop directly. When involuntary genetic contamination occurs, the monopolist eventually loses its advantage and stops its protection of GM seeds. A terminator gene can stop genetic contamination but imposes spillover costs on the traditional producers and reduces their outputs.
\end{abstract}

(c) 2012 Elsevier Inc. All rights reserved.

\section{Introduction}

Some regions of Austria, France, Spain, United Kingdom, Greece and Italy declared themselves as "the network of GMO-free regions" in November 2003. This declaration may be viewed as a measure to safeguard "genuine and high-quality products." These countries prohibited the cultivation of genetically modified (GM) crops even though the bans were not based on scientific risk studies. However, as the World Trade Organization (WTO) rules are implemented, the European Union (EU) is expected to drop the ban and gradually develop its own GM foods.

The EU recently approved the production of genetically modified potatoes. The European Food Security Authority (EFSA) reaffirmed that "the use of the npt2 gene does not pose a risk to human or animal health or to the environment." (BASF, 2009). Often, GM products are used as inputs in the production of other goods. For example, Cendrowicz (2010) reported that the GM potato created by BASF, a German chemical giant, was developed to produce higher levels of starch. Similarly, at India's Central Potato Research Institute (CPRI), scientists are developing "protato" which has 60\% more protein than the conventional potato varieties to feed the poor. This is an indication that the attitude toward GMOs is gradually changing in Europe and elsewhere.

As GM crops are gaining ascendancy, genetic contamination is emerging as an issue in developing countries. However, the consequences of genetic contamination have received scant attention in the literature. Gene transfer can occur in most crops when crops are grown in proximity to each other. Belcher, Nolan, and Phillips (2005) pointed out that gene transfer imposes spillover costs on the conventional producers. ${ }^{1}$ Barton and Dracup (2000) noted that genetic contamination depends not only on the proximity between fields planted with GM and traditional crops, ${ }^{2}$ but also on the size of two crop populations. As more acreage is used to plant a GM crop, the more likely it is that the remaining traditional crop will be contaminated. Toolsema (2008) suggests that genetic contamination may result in a market collapse in the conventional product. Zerbe (2009) noted that genetic

\footnotetext{
* Department of Economics, Iowa State University, Ames, IA 50011, USA. Tel.: +1 5152945999.

E-mail address: kchoi@iastate.edu.

${ }^{1}$ Belcher et al. (2005) note other social costs associated with gene transfer. These include, for example, human health risks attributable to GM crops, loss of biodiversity due to unusual persistence or invasiveness of GM varieties, and the escape of transgenes to other crops or wild relatives.

${ }^{2}$ For example, Perry (2002) notes that in the UK, GM forage maize should not be grown within 80 m of conventional crops and within $200 \mathrm{~m}$ of organic crops in order to limit cross-pollination to $1 \%$.
}

1059-0560/\$ - see front matter (c) 2012 Elsevier Inc. All rights reserved. http://dx.doi.org/10.1016/j.iref.2012.10.006

Please cite this article as: Choi, E.K., Genetic contamination of traditional products, International Review of Economics and Finance (2012), http://dx.doi.org/10.1016/j.iref.2012.10.006 
makeup of Mexican maize had been contaminated with genes from GM crops grown in the US. Specifically, "2004 sampling of 60 new fields found contamination in 11 sites, signaling that the problem is getting worse." Currently, the EU requires that any produce containing more than 0.9\% GM content must be labeled as such (Wuestneck, 2010).

The purpose of this paper is to analyze the consequences of genetic contamination of the traditional products. Section 2 lays out the basic model of competitive traditional producers and a single producer of a GM crop. Section 3 considers the competitive producers of the traditional and GM crops, but GM farmers buy the seeds from a single seller. These two models are shown to be equivalent under certain conditions. Section 4 investigates short run equilibrium when genetic contamination occurs and shows that the monopolist eventually relinquishes the protection of his GM seeds. Section 5 considers the implications of inserting a suicide gene into the GM crop to avoid genetic contamination. Section 6 contains the concluding remarks.

\section{The basic model without genetic contamination}

The basic North-South model of the GM and traditional crops, developed by Choi (2010), can be modified to consider a Cournot-Nash equilibrium in the absence of genetic spillovers. Consider two types of crop producers in the European Union. The traditional crop is produced by many competitive producers. Due to the extensive costs of developing GM crops, the producer of the GM product is assumed to be a monopolist. As in Toolsema (2008) assume that proper labels are required so that consumers knowingly purchase a GM product. The monopolist of the GM crop assumes that the output of the other industry is given. Likewise, competitive producers of the traditional crop assume the output of the GM crop is given.

The inverse demand for the traditional product in EU is given by:

$$
p=a-b Y-g X
$$

where $a, b$, and $g$, are positive constants, and $p$ and $X$ are the price and quantity of the GM crop produced by the monopolist. GM and traditional crops are indistinguishable by visual inspection. Accordingly, labels are required on the GM product to help consumers distinguish the two products. Note that they are close but not perfect substitutes, and the presence of the GM product decreases the demand for the traditional product $(g>0)$.

The inverse demand function for the GM product is given by:

$$
P=A-B X-G Y,
$$

where $P$ is the price of the GM product and $A, B$ and $G$ are a positive constants. Since the traditional product and the GM products are close substitutes, the slopes of cross-demand curves are less than those of own demand curves, i.e., $g<b$ and $G<B$.

\subsection{Traditional producers}

Assume that there are $n$ identical farmers producing the traditional product in the EU. Let $y$ denote the output of the representative producer, and $Y=n y$ be the total output of the traditional product by the European firms. The traditional farmer's problem is to choose $y$ to maximize profit

$$
\pi(y)=p y-c(y)
$$

where $c(y)$ is an individual farmer's production cost of the traditional crop. The traditional farmer's optimal output occurs where market price $p$ is equal to its marginal cost. The total profit of $n$ producers is

$$
\pi(Y)=n \pi(y)=n \pi(Y / n)=n p y-n c(y)=p Y-n c(Y / n),
$$

where $n c(Y / n)$ is the total cost expressed in terms of the aggregate output. Marginal cost of the aggregate output is $\mathrm{d}(n c(Y / n)) /$ $\mathrm{d} Y=c^{\prime}(y)$ for all $Y$. That is, the marginal cost of the aggregate output is the same as the marginal cost of the individual farmer. Accordingly, we may express the aggregate production cost in terms of the aggregate output, i.e., $c(Y) \equiv n c(Y / n)$. Thus, we can express the traditional farmers' problem as if there is only one traditional price-taking farmer choosing the aggregate output.

Assume that the number of traditional farmers is fixed in the short run. The representative traditional farmer chooses $y$ to maximize his profit,

$$
\pi=(a-b n y-g X) y-c(y)
$$

The traditional producer is a competitive price-taking firm. The first order condition is:

$$
\frac{\partial \pi}{\partial y} \equiv a-b Y-g X-c^{\prime}=0,
$$

which defines the European farmers' best response $Y=r(X)$ to the monopolist's output $X$.

Please cite this article as: Choi, E.K., Genetic contamination of traditional products, International Review of Economics and Finance (2012), http://dx.doi.org/10.1016/j.iref.2012.10.006 
Differentiating Eq. (6), we obtain the slope of the European firms' best response function,

$$
\left.r^{\prime}(X) \equiv \frac{\mathrm{d} y}{\mathrm{~d} X}\right|_{r}=-\frac{\pi_{y X}}{\pi_{y y}}=-\frac{g}{b n}<0,
$$

i.e., the representative European firm's output decreases as the monopolist increases its output. Since the two goods are imperfect substitutes, $b>g$ and $|\mathrm{d} n y / \mathrm{d} X|<1$.

\subsection{Monopolist of GM crop}

Next, consider the production decision of the monopolist. To produce a GM crop, the firm initially incurs large R\&D costs to create a new GM variety. R\&D costs are an entry barrier. Accordingly, entry into the GM product market is limited and a single firm in the US sells the GM product. R\&D costs are incurred only when a new variety is created, and are not a component of annual production costs. The monopolist's total cost is $C(X)=c(X)+e X$, where $e$ is the unit seed cost of the GM crop which must be incurred each year to maintain the genetic purity of its crop, and $c(X)$ is the non-seed production cost, common to all producers, whether they produce the traditional or GM crop. Monopoly profit is

$$
\Pi=(A-B X-G Y) X-c(X)-e X .
$$

The first order condition is

$$
\frac{\partial \Pi}{\partial X} \equiv A-2 B X-G Y-\left(c^{\prime}+e\right)=0
$$

where $M_{X}=P-B X=(A-2 B X-G Y)$ is marginal revenue.

While the monopolist is a price maker in its market, its output decision depends on the output of the traditional sector which produces a close substitute. Eq. (8) defines the monopolist's best response function, $X=R(y)$, to the European firms' aggregate output. Differentiating Eq. (8), we obtain the marginal response function of the monopolist,

$$
\left.R^{\prime}(y) \equiv \frac{\mathrm{d} X}{\mathrm{~d} y}\right|_{R}=-\frac{\Pi_{X y}}{\Pi_{X X}}=-\frac{G n}{2 B}<0 .
$$

(The slope of this function is: $\mathrm{d} y / \mathrm{d} X=-2 B / G n<0$ and $|\mathrm{d} y / \mathrm{d} X|>2 / n$.) Since $X$ and $Y$ are imperfect substitutes $(B>G$ and $b>g$ ), $B b>G g$. Thus, the monopolist's output decreases as the competitive industry expands. Let $\left(X^{o}, Y^{o}\right)=\left(X^{o}\right.$, ny $\left.y^{o}\right)$ denote the pair of outputs in the absence of genetic contamination at the Nash equilibrium. Combining the behavioral Eqs. (8) and (6), we obtain a Cournot-Nash equilibrium:

$$
\begin{aligned}
& X^{0}=\frac{b A^{*}-G a^{*}}{2 b B-g G}, \\
& Y^{0}=\frac{2 B a^{*}-g A^{*}}{2 b B-g G},
\end{aligned}
$$

where $A^{*}=A-C^{\prime}=A-\left(c^{\prime}+e\right)>0, a^{*}=a-c^{\prime}>0$, and $2 b B-g G>0$ to ensure positive outputs. Fig. 1 illustrates the CournotNash equilibrium in terms of total output $Y=n y$ of the traditional firms and the output of the GM product $X$.

\section{Monopoly of GM seed}

The innovative firms such as Monsanto and BASF do not engage in production activities directly but only sell the GM seeds to farmers who are willing to grow GM crops. Farmers may continue to produce the traditional variety or adopt the GM crop. We consider the production decision of an individual GM farmer who buys GM seeds. Assume that there are $m$ identical producers of GM crop, and one unit of seed yields one unit of the GM crop. For example, one seed grain yields one bushel of corn. Let $c(x)$ denote the non-seed unit production cost and $s$ be the price of the GM seeds imported from the United States. The GM crop producer's problem is to choose $x$ to maximize its profits,

$$
\phi(x)=P x-c(x)-s x
$$

The first order condition is:

$$
P=c^{\prime}(x)+s
$$

Please cite this article as: Choi, E.K., Genetic contamination of traditional products, International Review of Economics and Finance (2012), http://dx.doi.org/10.1016/j.iref.2012.10.006 


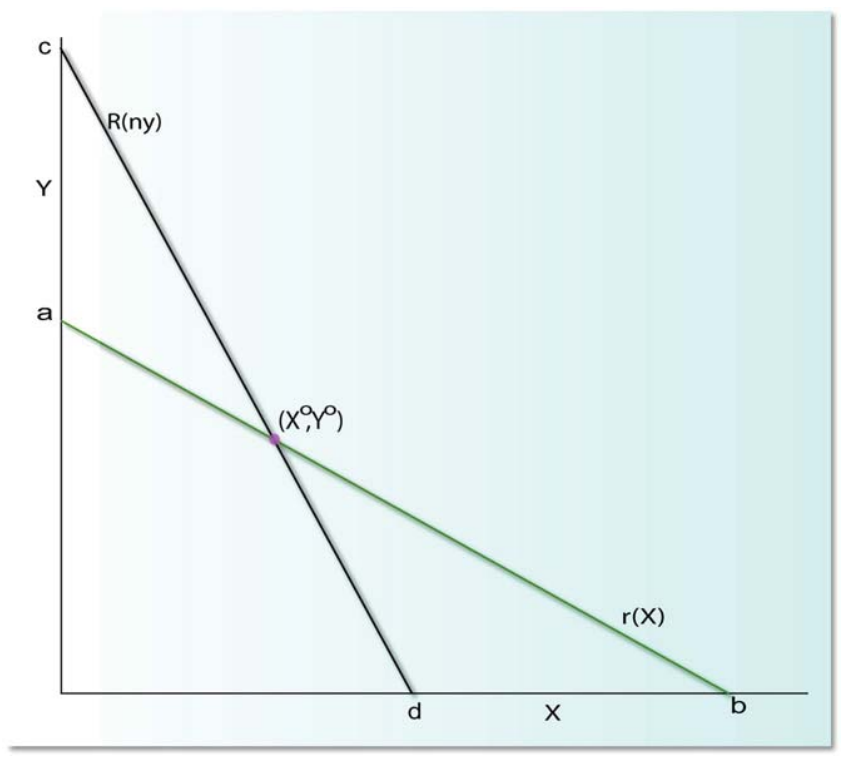

Fig. 1. Cournot-Nash equilibrium.

Fig. 2 illustrates a short run and the long run equilibrium in the market for the GM product. Since $P=c^{\prime}(X)+s$, a short run equilibrium occurs at $X^{\circ}$, where the proportional demand curve $D / m$ intersects the seed price-inclusive marginal cost curve, $c^{\prime}(X)+s$. However, since price exceeds unit cost $c / x+s$, the representative GM producer earns a positive profit and more firms enter the market.

How is the equilibrium number of GM farmers determined? There are no entry barriers to enter the GM crop industry, except that they have to buy the GM seed from a monopolist. If the industry profit is positive, more firms adopt the GM crop. Let $m^{*}$ denote the equilibrium number of GM producers. Let $\theta \equiv c(y) / y=c^{\prime}$ denote the minimum of non-seed average cost.

The equilibrium number $m^{*}$ of GM farmers needs to satisfy the zero profit condition:

$$
P=\theta+s
$$

In Fig. 2, a long run equilibrium occurs when the proportional demand curve $D / m^{*}$ intersects the industry's long run supply curve, $\theta+s$. Then the price must be equal to the minimum of average cost.

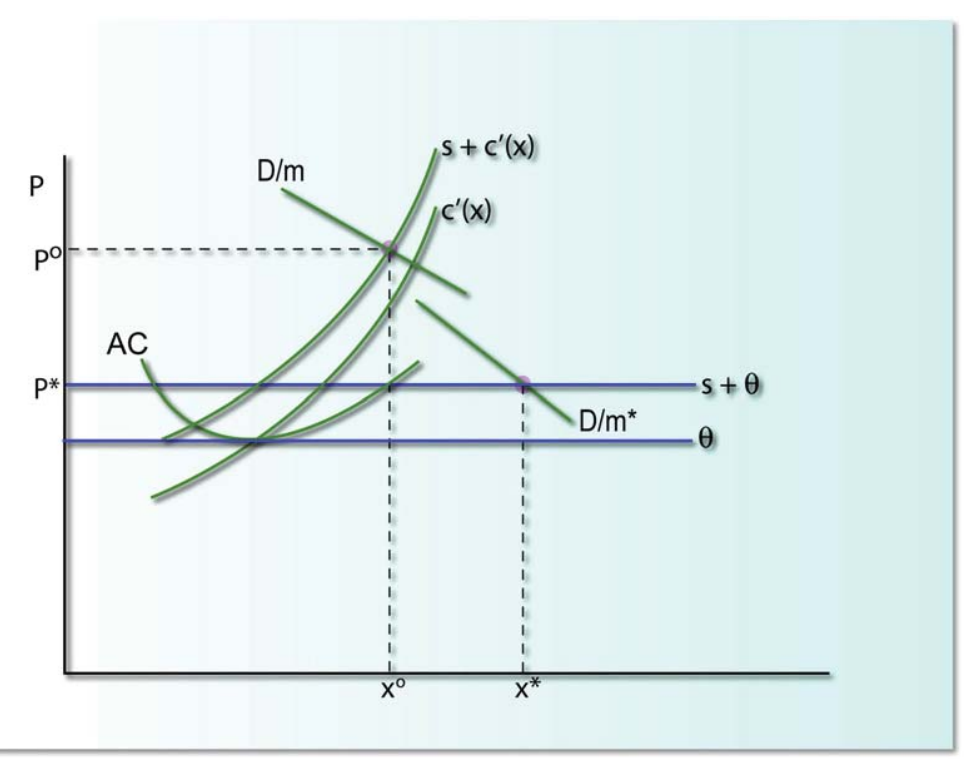

Fig. 2. Short run and long run equilibria.

Please cite this article as: Choi, E.K., Genetic contamination of traditional products, International Review of Economics and Finance (2012), http://dx.doi.org/10.1016/j.iref.2012.10.006 
Now we are in a position to consider the monopolist's seed production. From (13), the inverse demand for GM seeds can be written as $s=P-\theta$, or

$$
s=A-B X-G Y-\theta \text {. }
$$

Since there is a one-to-one correspondence between the quantities of the GM seed and their resulting crop, the monopolist's seed production decision amounts to deciding the total output of the GM crop.

The profit of the monopolist of the GM seed is:

$$
\Pi=s X-e X=(A-B X-G Y-\theta) X-e X,
$$

which is positive when $s>e$. The first order condition for optimum seed production is:

$$
\frac{\partial \pi}{\partial X}=A-2 B X-G Y-\theta-e=P-(\theta+e)-B X=0,
$$

where $M R \equiv P-\theta-B X$ and $M C=e$. The monopolist sets the seed price, $s=P-\theta$, which exceeds the unit cost of seed production, $e$. Recall that condition (8) requires $A-2 B X-G Y-\left(c^{\prime}+e\right)=0$. This condition reduces to Eq. (16) when there is an equilibrium number of GM producers in long-run equilibrium since $c^{\prime}=\theta$. This result is summarized below:

Proposition 1. If the competitive GM producers buy the GM seed from a monopolist and are in long-run equilibrium $(P=\theta+s)$, the resulting market equilibrium is the same as that achieved when the monopolist produces the GM crop directly.

\section{Genetic contamination of the traditional crop}

When the GM corn and the traditional corn are planted in the same region (e.g. EU), the traditional corn in one country is easily contaminated by the GM corn grown in another. Cross-pollination can be caused by birds, insects and wind without regard to national borders. Specifically, pollen from a GM crop in one country can easily be transferred to traditional crops in another unless the two countries are in different continents.

The reverse pollination does not occur because producers of the GM crop buy only the seeds grown in a controlled environment, a lab in the United States. ${ }^{3}$ As a result, GM seed costs more. The presence of GM crops in the same region makes it difficult for the traditional producers to maintain the DNA purity of the traditional crops. Each year a higher fraction of the traditional crops will become hybrids, and hybrids become more like the GM crop. Eventually, the contaminated traditional product and GM variety become indistinguishable not only visually, but also genetically.

Genetic contamination follows a geometric sequence. Let $b(0<b<1)$ denote the fraction of the traditional crop contaminated by the GM crop. After $n$ years, the fraction of the contaminated crop in a given field is: $b+b^{2}+\ldots+b^{n}$. For instance, $b=1 / 2$, after seven years, more than $99 \%$ of the traditional crop is contaminated by the GM crop. ${ }^{4}$ This is based on the assumption that the acreage used for the GM crop remains constant. If the rate of adoption of GM crops rises, this process will occur more quickly.

We now investigate the long-run equilibrium of the two crops in the absence of intervention, i.e., when genetic contamination of the traditional crop is complete. This occurs when genetic contamination of the traditional crop exceeds a given threshold, say $50 \%$. At present, the EU requires that any produce containing more than $0.9 \%$ GM content must be labeled as such. Once the threshold is reached, the contaminated crop is no longer labeled as a "traditional" crop, and is treated as a GM crop. Thus, consumers no longer distinguish the highly contaminated traditional crop and the pure GM crop $(b=g=G=B$ and $p=P)$. As a result, there is only one market for one product $(a=A, b=B)$. The inverse demand for the contaminated or GM crop is:

$$
p=a-b(Y+X)
$$

The profit of the traditional producers is:

$$
\pi=(a-b(Y+X)) Y-c(Y),
$$

and their first order condition is: $p-c^{\prime}=0$. The profit of the GM crop producer is:

$$
\Pi=(a-b(X+Y)) X-(\theta+e) X,
$$

where $e$ is marginal cost of GM seed. The first order condition is:

$$
a-(2 b X+b Y)-(\theta+e)=0 .
$$

\footnotetext{
${ }^{3}$ A GM seed variety is created by genetically introducing foreign DNA into the plant, but this process is imprecise and hazardous. According to Mae-Wan Ho, the process may unleash a deadly Andromeda strain.

${ }^{4}$ Moreover, the contaminated seeds within the crop further contaminate the rest, but the potency is diluted over time. 


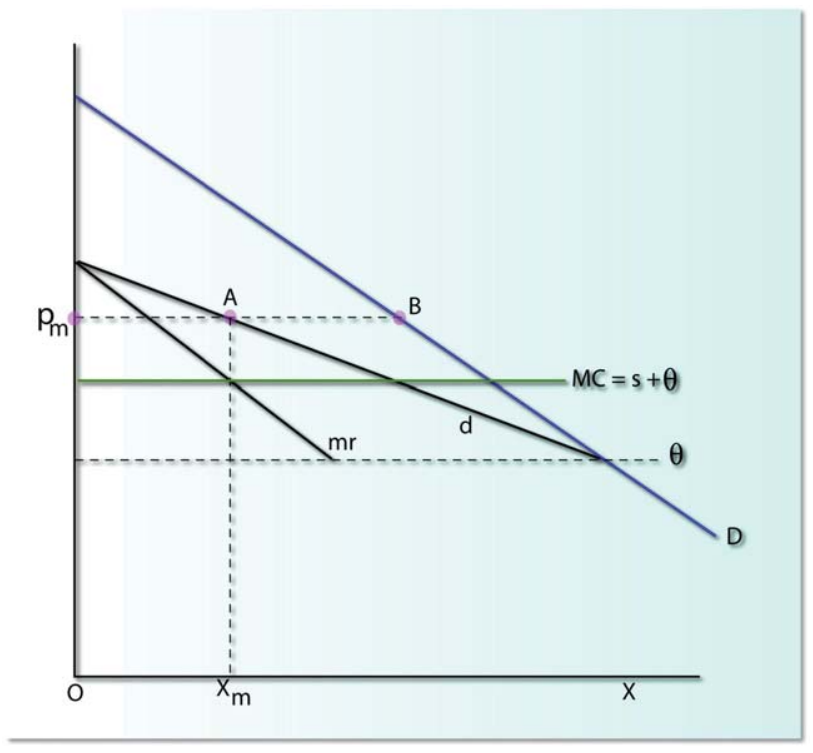

Fig. 3. Shrinking demand for GM seed.

This production problem is similar to that of a dominant firm with a competitive fringe.

When the GM and traditional crops become indistinguishable genetically, there is only one market demand curve D for all producers, as shown in Fig. 3. The demand curve facing the monopolist (d) is obtained by subtracting the supply curve of the traditional producers. The monopolist's output occurs at point $Q_{\mathrm{m}}$, where marginal revenue $(\mathrm{mr})$ and marginal $\cos t(M C=e+\theta)$ intersect. The GM crop producer is the price leader and sets the price $\left(p_{\mathrm{m}}\right)$. The traditional producers' output is $\mathrm{AB}$.

Even though GM farmers earn zero profit, the situation in Fig. 3 describes a short- run equilibrium. If the representative competitive firm earns a positive profit, more firms will enter the market. Thus, each year the monopolist faces a shrinking demand curve. In the long run, price falls to unit cost of the competitive producer, which is lower than that of the monopolist. Since the monopolist receives the same price as the competitive firms, there is no need for the monopolist to preserve the genetic purity of the GM crop. Thus, the monopolist quits protecting its seeds. These results are summarized below:

Proposition 2. Assume that each year involuntary contamination of the traditional crop occurs between two countries and that a country initially imports GM seed. If the cost of maintaining purity of the GM seed $e$ is positive and the non-seed unit production cost of GM crop and the traditional crop are identical, $c(y) / y=\theta$, the monopolist eventually relinquishes the protection of seed purity, seed trade stops, and the long-run equilibrium crop is a hybrid of the traditional and GM crops.

Intuitively, this proposition suggests that the GM producer earn positive profits from one-off innovation in the short run, but eventually is wiped out by the competitive traditional producers. As a result, the country stops importing the GM seed. It is not possible for the monopolist to invest once in a GM crop and earn profits forever. In order to stay ahead of the competitive producers of the traditional crop, the GM producer must continue to support periodic genetic innovation.

\section{Terminator gene}

Involuntary genetic pollution can be prevented by inserting a terminator or suicide gene to the GM crop. This process does not change the production cost of the GM crop. The terminator technology was developed in 1988 in order to protect the patents of GM seed producers. However, pollen from such genes will produce sterile seeds in the traditional plants. Each year the plants would grow for only one crop season and produce sterile seeds like the seedless watermelons. When pollen from the GM crop in one country are transferred to the traditional crop in another by wind, insects, or birds, they do not produce reproductive seeds. As the proportion of sterile seeds increases, output of the contaminated traditional crops declines and hence increases production cost. Thus, the suicide gene in the GM crop imposes spillover costs on the traditional producers in another country. Since this is a politically sensitive issue, Monsanto announced its intention not to pursue technologies that render seed sterile (Shapiro, 1999), but this may not be a permanent position.

The profit of the GM crop is not directly affected by the suicide genes, but only indirectly through a change in the outputs of the competitive traditional producers. When the GM seed with the suicide gene is planted, the monopolist's profit is

$$
\Pi=(A-B X-G Y) X-C(X)
$$

Please cite this article as: Choi, E.K., Genetic contamination of traditional products, International Review of Economics and Finance (2012), http://dx.doi.org/10.1016/j.iref.2012.10.006 
Profit of the traditional firms are given by:

$$
\pi=(a-b Y-g X) Y-(1+\beta) c(Y),
$$

where $\beta(>0)$ indicates that the suicide gene imposes spillover costs on the traditional producers. For instance, if $\beta=1$, half the pollination work is done by the pollen with the suicide gene, $1 /(1+\beta)=1 / 2$, then output declines by half. Thus, when $\beta=1$, the production cost doubles. If $\beta=2$, two thirds of the pollination work is achieved by the pollen with suicide genes, and the output declines to one-third. Thus, the terminator gene raises the production cost of the traditional crops. The first order condition is:

$$
\frac{\mathrm{d} \pi}{\mathrm{d} Y}=(a-b Y-g X)-(1+\beta) c^{\prime}=0 .
$$

Thus, the marginal spillover cost shifts the best response curve of the traditional producers downward in Fig. 1. These results are summarized below:

Proposition 3. When a suicide gene is inserted into the GM crop to stop its genetic contamination of the traditional crop, the output of the GM crop increases while that of the traditional crop declines.

Instead of suffering the consequences of the terminator gene, traditional farmers can protect their own seeds by growing them in a controlled environment. Alternatively, the traditional farmers can take legal action against the GM seed firm to pay for the damage. Also, the traditional producers in the seed importing country may erect barriers to block the cross-pollination with the GM crops. This is a spillover cost for the traditional producers.

\section{Concluding remarks}

This paper considered the effects of genetic contamination of traditional crops by GM seeds. When the two types of crops are planted in the same region, eventually the traditional crops are contaminated by the GM crops due to wind, insects and birds. Moreover, as the two crops become indistinguishable, there is no need for the monopolist to protect the GM seeds. Eventually, seed trade stops and all farmers produce a hybrid crop.

The majority of GM products are produced by high-income countries and sold in developing countries. It may be socially desirable to reduce genetic contamination and preserve the traditional varieties. Toolsema (2008) notes that in the introduction stage the EU requires that GM farmers take proper preventive measures to deter genetic contamination. Tariffs or quotas on GM seed may transboundary delay genetic contamination. ${ }^{5}$

If the traditional variety is highly prized by consumers, producers of the traditional crop can designate one of them to grow their seeds in a controlled environment. Protection of the traditional seeds may be costly, but in the face of crop diseases and uncertainty it may be socially desirable to protect the genetic purity of traditional as well as GM crops.

\section{Acknowledgments}

The author is indebted to two anonymous referees for their helpful comments. The usual caveats apply.

\section{References}

Barton, J. E., \& Dracup, M. (2000). Genetically modified crops and the environment. Agronomy Journal, 92, 797-803.

BASF (2009). EFSA reconfirms the safety of Amflora, BASF's genetically modified potato. http://www.basf.com/group/pressrelease/P-09-146 (accessed February $10,2011)$.

Belcher, Ken, Nolan, James, \& Phillips, Peter W. B. (2005). Genetically modified crops and agricultural landscapes: Spatial patterns of contamination. Ecological Economics, 53, 387-401.

Cendrowicz, Leo (2010). Is Europe finally ready for genetically modified foods? http://www.time.com/time/business/article/0,8599,1970471,00.html (accessed February 4, 2011).

Choi, E. Kwan (2010). International trade in genetically modified products. International Review of Economics and Finance, 19, 383-391.

Lapan, Harvey, \& Sikdar, Shiva (2011). Strategic environmental policy under free trade with transboundary pollution. Review of Development Economics, 15, 1-18.

Perry, J. N. (2002). Sensitive dependencies and separation distances for genetically modified herbicide-tolerant crops. Proceedings of the Royal Society of London, Series B: Biological Sciences, 269, 1173-1176.

Shapiro, Robert M. (October 4). Open letter from Monsanto CEO Robert B. Shapiro to Rockefeller Foundation President Gordon Conway. http://www.biotech-info. net/monsanto_letter.pdf (accessed, February 1, 2011).

Toolsema, L. (2008). Competition with Mandatory Labeling of Genetically Modified Products. Journal of Institutional and Theoretical Economics, 164, 429-448.

Wuestneck, Bernd (2010). Is Europe finally ready for genetically modified foods? http://www.time.com/time/business/article/0,8599,1970471,00.html (accessed January 27, 2011).

Zerbe, Leah (March 18). Genetically Modified DNA contaminates ancient Mexican Maize. http://www.rodale.com/gmos-and-corn-contamination (published March 18, 2009; accessed, February 1, 2011).

${ }^{5}$ For instance, Lapan and Sikdar (2011) consider strategic trade policies to deter transboundary pollution.

Please cite this article as: Choi, E.K., Genetic contamination of traditional products, International Review of Economics and Finance (2012), http://dx.doi.org/10.1016/j.iref.2012.10.006 
lowa State University does not discriminate on the basis of race, color, age, religion, national origin, sexual orientation, gender identity, genetic information, sex, marital status, disability, or status as a U.S. veteran. Inquiries can be directed to the Director of Equal Opportunity and Compliance, 3280 Beardshear Hall, (515) 294-7612. 